JPPIPA, Vol.6 No.1 2021
Jurnal Penelitian Pendidikan IPA
http:/journal.unesa.ac.id/index.php/jppipa

\title{
TRAINING NATURAL SCIENCE EDUCATION STUDENTS AS A PRE- SERVICE TEACHER IN CONSTRUCTING ASSESSMENT INSTRUMENTS OF COGNITIVE DOMAIN THROUGH CONSTRUCTIVIST CLASSROOM
}

Qurrotul Anfa

Nat. Sci. Edu. Program, Sekolah Tinggi Keguruan dan Ilmu Kependidikan Modern Ngawi, Indonesia

\begin{abstract}
This research aimed at training science education students as a pre-service teacher in constructing assessment instruments of cognitive domain through constructivist classroom. The modification of constructivist classroom in material of cognitive domain test assessment procedures was developed by researcher. The subject of this research were 22 college students semester V of natural science education students at STKIP Modern Ngawi. The study used pre-experimental design and the kind of that design is one-shot case study. The instruments used for analyzing the competences in constructing assessment instruments of cognitive domain was by students learning outcomes completeness sheet. The college students will be said to be complete their competences if they sufficient Criterion Referenced Evaluation specifically more than equal to $75 \%$. Empirically, the result of students completeness result as a whole was $86.50 \%$ and the category is valid. It means that natural science education students can construct well assessment instruments of cognitive domain trough constructivist classroom.
\end{abstract}

Keywords: Constructivist classroom, Constructing assessment, Cognitive domain

(C) 2021 Universitas Negeri Surabaya 


\section{INTRODUCTION}

In Indonesia, Presidential Regulation No. 2 of 2015 concerning the 2015-2016 National Medium Term Development Plan mandates that one of the most important aspects in ensuring the quality of education services is to provide a comprehensive assessment. A comprehensive assessment must be able to cover various aspects of attitudes, knowledge and skills (Azwar, 2015). In the Big Indonesian Dictionary, comprehensive means complete (regarding the scope or content), so when comprehensive associated with assessment it talks about how we assess attitudes, knowledge and skills of students.

By science learning evaluation subject we certainly can talk about how we assess attitudes, knowledge and skills of students. But for in this case, the science education students semester $\mathrm{V}$ of STKIP Modern Ngawi were trained to make cognitive assessment instruments. It is not easy to train them if previously they were not familiar with assessment instruments at all. So, it was better to start teaching by cognitive domain material first. At the end the quality of the learning outcome assessment instrument has a direct effect on the accuracy of the status of student achievement. Therefore, the position of the learning outcome assessment instrument is very strategic in supporting students as pre-service teacher decisions apropriated to achievement of student learning outcomes. The Minister of Education and Culture of the Republic of Indonesia's Regulation Number 23 of 2016 concerning to standards of assessment states that assessment is the legal action for collecting and processing information measuring the achievement of student completeness result.

In another case for increasing the learning process that is being apllied, increasing the quality of learning can be done by improvements to the instruments of assessment used to measure student completeness result. Improvements in the assessment aspect can be made by providing guidance and training in conducting assessments (Kartowagiran \& Jaedun, 2016)

Some experts interpret the meaning of assessment as follows Arikunto (2005) states that assessment is making a decision on something with good and bad measures. According to Widoyoko (2016), defines assessment is like an proccess by measuring and interpret data based on specific criteria and rules also. From both definitions are concluded that the assessment is called systematic and continuous' series activities for obtaining data and information. Those are like the learning process and students completeness result. The activities like analyzing the differences of traditional and authentic assessment; creating the table of question grids; creating item test; and creating rubric of answer test and scoring guidelines.

For training and encouraging of those six activities is needed a learning strategy. Students as pre-service teacher build their own knowledge, and then they develop through their interaction with environment, and do the authentic assignments. According to Raida \& Jamaludin (2020) said that students are actively involved in finding meaning, enthusiastic, productive, motivated in class, more confident, and able to apply skills and knowledge to further activities.

Based on mounting research of Marlowe \& Page (2005), the experiences as a educators, and reports from pre- and in-service teachers support the belief that constructivist, active learning programs are not only more engaging, but promote elaborate knowledge construction. However even when educators recognize the value of and want to and try to use constructivist classroom, their efforts often produce less than what they expect.

According to Piaget and Vygotsky as quoted by Eggen \& Kauchak (2001), there are four main keys to learning according to the constructivist teaching and learning, namely: 1) students compile more of their understanding, rather than getting it directly from the teacher; 2) new knowledge students have, depending on students' understanding of the subject matter previously obtained; 3) learning accompanied by scientific social interaction; and 4) learning tasks should supporting learning that is useful for students and appropriate with the subject material,

Constructivist classroom is like a step which draws on students' existing knowledge, beliefs, and skills. Trough constructivist approach, students synthesize new understanding from prior learning and new information. In constructivist learning, a teacher sets up problems and monitors student exploration, guides student inquiry, and promotes new patterns of thinking. Constructivist teaching asks students how to work with their own data and learn to direct their own explorations. Fortunately and ultimately, students begin to think of learning as accumulated, evolving knowledge (Barman \& Bhattacharyya, 2015).

College students, especially natural science education students in STKIP Modern Ngawi had studied about natural science like basic physic, biology or chemistry. It can supported them to construct assessment instrument and develop it into a proper test because they can learn more about the basic of those materials (physics, biology or chemistry). Meanwhile they were provided the initial knowledge about cognitive 
domain material first before constructing assessment instruments of cognitive domain facilitated by lecturer trough constructivist classroom.

The steps of constructivist classroom was adopted from Hevria (2019). The method has six learning stages, namely: 1) Engaging, 2) Grouping, (3) Evolving, (4) Clarifying, (5) Presenting, (6) and Reflecting. This constructivist learning method is more maximally used by utilizing learning resources. In this research, learning resources in this constructivist classroom was prepared by lecturer and science education students. The students gave their learning resources to the lecturer so that the lecturer can gave clarifying easily before asking the students for doing a presentation of discussion result. Finally, the student can construct assessment instruments of cognitif domain independently.

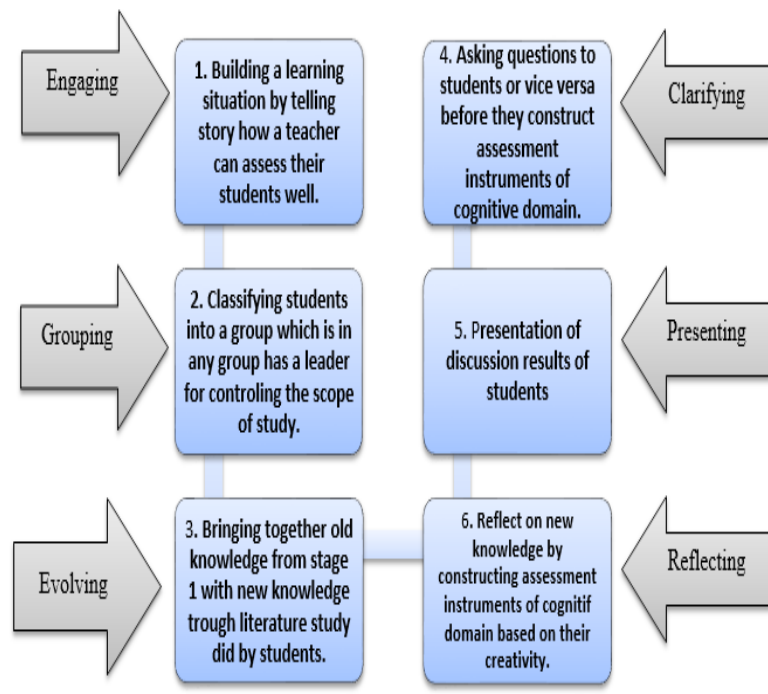

Figure 1. Steps of constructivist classroom to train science education students in constructing assessment instruments of cognitive domain adopted from Hevria (2019).

Natural science education is still dealing with a reality that is not quite pleasant. The world of education is still colored with practices that actually hinder the process of "dismantling" students truly (Gray, 1997). Most schools still translate natural science education as a transfer of knowledge. Most schools still translate it as a transfer of knowledge. Learning is more colored by memorizing theories or formulas. Such a method is applied in the hope that students are able to answer various questions. Ironically, this method is close to being unable to translate various theories or formulas into the realities that surround students. Therefore education is not sufficient to provide life skills to students.
Based on the background above in this research was aimed at training natural science education students in constructing assessment instruments of cognitive domain through constructivist classroom with various considerations that had been previously analyzed.

\section{METHOD}

The study used pre-experimental design and the kind of that design is one-shot case study. 22 science education students in natural science education STKIP Modern Ngawi are the subject in this study. They also were joining science learning evaluation course. This study was implemented for three weeks, starting from $14^{\text {th }}$ to $28^{\text {th }}$ of October 2020. Material of this course which were applied to train science education students in constructing assessment instruments of cognitive domain were developed by lecturer. The improvement of constructivist classroom in material of cognitive domain assessment procedures were developed by researcher.

$$
\begin{gathered}
\text { Score percentage }= \\
(\text { total score of analyzed }) /\left(\sum \text { maximum score }\right) \times 100 \% \\
\hline
\end{gathered}
$$

Figure 2. The formula to calculate score percentage.

The results were calculated by the following formula above and analyzed using assessment criteria. The research instrument used to measure cognitive domain constructability of science education students was an essay test instrument consist of four items. This test was given only in one stage because it was intended to show the power of measurement and the scientific value of a research design. The standard used related to measure cognitive domain constructability if the percentage of the students who completed it reached until $75 \%$ of the students. It used Criterion Referenced Evaluation because it is an assessment approach model which refers to a predetermined goal achievement criteria. According to Linn \& Grondlund (2000), Criterion Referenced Evaluation is a way of determining student competences using a number of standards. When students have met these standards, they are declared successful. But if the student has not met the standards, it is said to have failed or have not mastered the learning material. The values obtained by students are related to the level of achievement of student mastery of learning material in accordance with predetermined goals. 
answer well. The total percentage of indicator completeness is $86.50 \%$. It means that by constructivist classroom students can achieve a learning outcome in analyzing the differences of traditional and authentic assessment. Then, at the second indicator is creating the table of question grids. That is $79.74 \%$. Almost of students can answer well. It just because they could not analyze the cognitive domain in their table of question grids properly. At the third indicator got the highest percentage. That is $91.47 \%$. In this part almost of student answer correctly because it was simply for constructing item test only adjusted from the table of question grids student created. The last indicator is creating rubric of answer test and scoring guidelines. The percentage is quite high even in the making of rubric of answer test and scoring guidelines is not as easy as with making item test only. It is $88.27 \%$. It means that by constructivist classroom students can achieve a learning outcome in creating rubric of answer test and scoring guidelines.

The completeness of student learning outcomes was related with the steps of constructivist classroom. In the first step of constructivist classroom, engaging time is building a learning situation by telling story about how a teacher can assess their students well it can make students motivated. Motivated students will also have better metacognitive skills and have more resilience in finishing their tasks (Pintrich \& De Groot, 1990). Then learners who are motivated will spend a lot of time trying also, and achieving higher learning accession than those who are less or not motivated (Salili et al., 2001).

In another case in the fourth step, it is clarifying. The opportunity for discussion and feedback from the teacher will have a positive impact on learning attitudes and student performance. The study states that learners assume that with discussions they can share ideas and complement each other's understanding. Learners also think that the feedback from teachers will improve the quality of their understanding and work (Sabtiawan et al., 2019).

\section{CONCLUSSION}

The findings represented that constructivist classroom was empirically valid to train science education students in constructing assessment instruments of cognitive domain as a pre-service teacher. The student completeness result received $86.50 \%$. It means that natural science education students can construct well assessment instruments of cognitive domain trough constructivist classroom.

\section{REFERENCES}

Arikunto, Suharsimi. (2005). Dasar-Dasar Evaluasi Pendidikan. Jakarta: Bumi Aksara.

Azwar, Saifuddin. (2015). Validitas dan Reliabilitas Edisi ke-4. Yogyakarta: Pustaka Belajar.

Barman, Pranab \& Bhattacharyya, D. Dibyendu. (2015). Effectiveness of Constructivist Teaching Method: An Experimental Study. International Journal of Research in Social Sciences And Humanities, 5(1), 69-76.

BSNP. (2016). Standar Penilaian Pendidikan. Jakarta: Departemen Pendidikan Nasional Dirjen Dikdasmen.

Eggen, P and Kauchak, D. (2001). Educational Psychology: Classroom Connections $5^{\text {th }}$ edition. New York: Macmillan.

Gray, Audrey. (1997). Contructivist Teaching and Learning. SSTA Research Centre Report, 97-07.

Hevria, Silvi. (2019). Constructivist Learning Model Using Portal Rumah Belajar for Primary School Student. Advances in Social Science, Education and Humanities Research, 372, 268-271.

Kartowagiran, B., \& Jaedun, A. (2016). Model Asesmen Autentik untuk Menilai Hasil Belajar Siswa Sekolah Menengah Pertama (SMP): Implementasi Asesmen Autentik di SMP. Jurnal Penelitian dan Evaluasi Pendidikan, 20(2), 131-141.

Linn, Robert L. and Norman E. Gronlund. (2000). Measurement and Evaluation in Teaching Seventh Edition. New York: Macmillan Publishing Company.

Marlowe, Bruce A., \& Page, Marilyn L. (2005). Creating and Sustaining the Constructivist Classroom First Edition. Michigan: SAGE Publication.

Pintrich, P. R., \& de Groot, E. V. (1990). Motivational and self-regulated learning components of classroom academic performance. Journal of Educational Psychology, 82(1), 33-40.

Peraturan Pemerintah RI. (2015). Standart Nasional Pendidikan. Jakarta: Departemen Pendidikan Nasional.

Raida, S.A., \& Jamaludin, D.N. (2020). The Effectiveness of Constructivist Learning Using Guided Discovery Models on The Concept of A Regulatory System for Curiosity and AntiNarcotics Attitudes. Thabiea: Journal of Natural Science Teaching, 3(1), 41-50.

Sabtiawan, W. B., Yuanita, L., \& Rahayu, Y. S. (2019). Effectiveness of Authentic Assessment: Performances, Attitudes, and 
Prohibitive Factors. Journal of Turkish Science Education, 16(2), 156-175.

Salili F, Chiu CY, \& Lai S. (2001). The influence of culture and context on Students: Motivational orientation and performance. In: Salili F, Chiu C, Hong Y, editors.
Student motivation: The culture and context of learning. London: Plenum. pp. 221-247.

Widoyoko, Eko. (2016). Penilaian Hasil Pembelajaran di Sekolah. Yogyakarta: Pustaka Pelajar. 